\title{
STRENGTHENED SEED REGULATIONS AND CERTIFICATION SYSTEM IN
}

\section{AFGHANISTAN}

Improving smallholder farmers' access to high-quality seeds is among the key objectives of CGIAR. Achieving this goal requires a conducive policy and regulatory environment. Partnerships between public and private stakeholders for seed certification have proven successful in many countries. In Afghanistan, the engagement of CGIAR with the government resulted in a strengthened seed certification and seed market system through implementation of the public-private-producers partnership business model.

The laws and procedures that regulate the seed sector in the country had not been updated for over a decade when ICARDA scientists started to work on this topic with the government in 2015.

Following a review of the seed certification system in Afghanistan and neighboring countries and a study highlighting key constraints and opportunities, the team ran a baseline survey of 26 private seed companies, 5 seed-testing laboratories, and 105 farmer households in the Herat, Kabul, and Nangarhar provinces. This survey revealed the insufficient quantity and quality of certified seeds available to farmers. About $76 \%$ of farmers said that the quality of certified seeds available in the market was low and $91 \%$ of farmers believed that the quantity of those seeds was insufficient. Furthermore, $98 \%$ of survey participants agreed that third-party seed certification based on the public-private-producer partnership model would improve the quality of certified seed being marketed.
Partners: Afghanistan National Standards Authority, European Union, International Center for Agricultural Research in the Dry Areas (ICARDA), Ministry of Agriculture, Irrigation and Livestock of Afghanistan, Punjab Agricultural University.

Years: $2015-2019$

PIM Research Area: Technological Innovation and Sustainable Intensification

Geographic Focus: Afghanistan

Corresponding Researcher:

Dr. Nigamananda Swain

(ICARDA Afghanistan)

Based on these results and in partnership with national agricultural research systems and private sector stakeholders, ICARDA and the Ministry of Agriculture, Irrigation and Livestock developed key documents in support of the seed policy reform. A mechanism for third-party seed certification was established, with procedures to apply penalties for non-compliance. Guidelines on the general requirements of certified seed production, field inspection, postharvest management of seed, seed sampling techniques, seed testing and control were developed, published in local language, and distributed to stakeholders. National Seed Quality Control Standards for 38 vegetable crops and 19 fruit crops developed in collaboration with the Afghanistan National Standards Authority were approved in 2019 by the Standard High Council chaired by the Vice-President of Afghanistan, and are now being implemented throughout the country. Guidance for seed producers was made available on the Afghanistan Seed Certification Agency website. Workshops, learning visits and training programs were conducted for about 1,000 staff of seed-testing laboratories, Provincial Directorates of Agriculture, Irrigation and Livestock and private seed companies on the application of the new guidelines and regulations. 


\title{
Also see:
}

Yashpal Saharawat, Sayed Samiullah Hakimi, Faridullah Sherzad, Srinivas Tavva, Nigamananda Swain, Zewdie Bishaw, Abdoul Aziz Niane (2017). Public-Private-Producers Partnership for Strengthening Seed Certification in Afghanistan: Review of Seed Regulatory System in Afghanistan and Neighboring Countries. Lebanon: International Center for Agricultural Research in the Dry Areas (ICARDA).

https://hdl.handle.net/20.500.11766/8153

Hamid Salari, Mahboobullah Nang, Michael Larinde, Sayed Samiullah Hakimi, Faridullah Sherzad, Yashpal Saharawat, Srinivas Tavva, Nigamananda Swain, Zewdie Bishaw, Abdoul Aziz Niane, Hayatullah Kamalzai (2017). Public-Private-Producers Partnership for Strengthening Seed Certification in Afghanistan: Afghanistan Seed Certification System: Constraints and Opportunities. Beirut, Lebanon: International Center for Agricultural Research in the Dry Areas (ICARDA). https://hdl.handle.net/20.500.11766/8165

Srinivas Tavva, Yashpal Saharawat, Sayed Samiullah Hakimi, Faridullah Sherzad, Nigamananda Swain (2017). Public-Private-Producers Partnership for Strengthening Seed Certifcation in Afghanistan: Baseline Survey Report. Lebanon: International Center for Agricultural Research in the Dry Areas (ICARDA). https://hdl.handle.net/20.500.11766/8164

\begin{abstract}
Sayed Samiullah Hakimi, Hamid Salari, Mahboobullah Nang, Faridullah Sherzad, Yashpal Saharawat, Michael Larinde (2017). General Guidelines for Seed Certification: Public-Private-Producers Partnership for Strengthening Seed Certification in Afghanistan. Beirut, Lebanon: International Center for Agricultural Research in the Dry Areas (ICARDA). https://hdl.handle.net/20.500.11766/9847
\end{abstract}

Nigamananda Swain (2019). DCI-ASIE Public Private Producers Partnership for strengthening seed certification in Afghanistan. Final Report. Beirut, Lebanon: International Center for Agricultural Research in the Dry Areas (ICARDA). https://hdl.handle.net/20.500.11766/11019

\section{About PIM}

Policies, Institutions, and Markets (PIM) is one of CGIAR's Global Integrating Programs, focused on addressing the policy, institutional, and market constraints to sustainable and equitable economic development and rural transformation. Such roadblocks include regulations restricting adoption of technologies by smallholder farmers, inefficient allocation of public resources, market failures or missing markets, weak property rights, restrictive gender norms and practices, and exposure of smallholders to shocks and risks. PIM aims to address these constraints through four main channels: global agenda setting, national policy support, program and market innovations, and capacity development. www.pim.cgiar.org

This publication has been prepared as an output of the CGIAR Research Program on Policies, Institutions, and Markets (PIM) led by IFPRI and has not been independently peer reviewed. Any opinions expressed here belong to the author(s) and are not necessarily representative of or endorsed by IFPRI, PIM, or CGIAR.

\section{CGIAR RESEARCH PROGRAM ON POLICIES, INSTITUTIONS, AND MARKETS}

